Jan Mironczuk

Wyższa Szkoła Teologiczno-Społeczna, Warszawa

Wyższe Baptystyczne Seminarium Teologiczne, Warszawa

\title{
Wyznania protestanckie na obszarze dystryktu podlaskiego
}

Praca składa się z wprowadzenia, trzech podrozdziałów i zakończenia. We wprowadzeniu ukazano cele pracy, wyjaśniono stosowaną terminologię oraz podano podstawę źródłową. W pierwszym podrozdziale przybliżono genezę reformacji na Podlasiu, w tym rolę Mikołaja Radziwiłła „Czarnego”. Kolejno przedstawiono wykaz zborów protestanckich na obszarze istniejącego w latach 1560-1796 dystryktu podlaskiego oraz ukazano „dole i niedole” wiernych protestanckich pozostających pod protekcją możnych Radziwiłłów. Całość wieńczy zakończenie, gdzie udzielono odpowiedzi na problemy badawcze postawione we wprowadzeniu.

The article is divided into an introduction, three subchapters, and a conclusion. The introduction explains the purposes of the study, and the terminology used as well as presents the source basis. In the first subchapter, a genesis of the Reformation in Podlasie Region is outlined, with a role played by Mikołaj "The Black" Radziwiłł. Next, a list of Protestant churches is presented in the district of Podlasie existing in 1560-1796, together with the vicissitudes of the Protestants under the protection of the Radziwiłłs. The study closes with a conclusion containing the answers to the research questions posed in the introduction.

Słowa kluczowe: Podlasie, Wielkie Księstwo Litewskie, reformacja, dystrykt, zbory, Radziwiłłowie, patronat

Ke yw ords: Podlasie, Grand Duchy of Lithuania, Reformation, district, Protestant churches, Radziwiłłs, patronage 
Wprowadzenie

Celem pracy jest próba zarysowania dziejów wyznań protestanckich na obszarze dystryktu podlaskiego, wchodzącego w skład prowincji litewskiej (Jednoty Litewskiej) Kościoła ewangelicko-reformowanego. Poniżej omówione zostaną następujące kwestie: przyczyny i uwarunkowania rozwoju reformacji na omawianym terenie, okoliczności powstawania zborów i ich egzystencji w zmieniającej się rzeczywistości polityczno-społecznej, a także rola protektorów, zarówno w początkach istnienia wspólnot protestanckich, jak i w okresie postępującej kontrreformacji.

$\mathrm{Na}$ wstępie warto zwrócić uwagę, że historyczna kraina Podlasie rozciąga się obecnie na obszarze województwa podlaskiego, a ściślej jego centralnej i południowej części, oraz wschodnich krańcach województwa mazowieckiego i północnych lubelskiego. W latach 1513-1566 województwo podlaskie obejmowało także ziemie brzeską, kobryńską i kamieniecką (obecnie w obwodzie brzeskim Republiki Białorusi). Powstały u schyłku okresu „dużego” Podlasia wspomniany dystrykt obejmował swym zasięgiem głównie dwa województwa: podlaskie - wcielone do Korony tuż przed unią lubelską, i brzeskolitewskie - pozostające w Wielkim Księstwie Litewskim. Cezurę końcową dla analiz i wniosków zaprezentowanych w artykule wyznacza likwidacja dystryktu podlaskiego, tuż po upadku Rzeczypospolitej.

Dominującą rolę w inicjowaniu i wspieraniu wyznań reformacyjnych na obszarze dystryktu podlaskiego odegrali Radziwiłłowie. Zachowane źródła ilustrujące omawiane poniżej zagadnienia znajdują się m.in. w zespole Archiwum Warszawskie Radziwiłłów przechowywanym w Archiwum Głównym Akt Dawnych w Warszawie. Pozwalają one na bezpośrednią obserwację form funkcjonowania tychże wyznań w XVII i pierwszej połowie XVIII w., nie odnaleziono tam jednak interesujących dokumentów z okresu wcześniejszego. Do początków reformacji w województwie podlaskim odnoszą się natomiast $\mathrm{w}$ pewnym stopniu znakomite opracowania, które w określonym kontekście przybliżają omawiane zjawisko. Wskazać tu należy monografie o pierwszym protektorze reformacji w Wielkim Księstwie Litewskim, Mikołaju Radziwille „Czarnym”1 oraz o patronie zborów

1 Zob. J. Jasnowski, Mikotaj Czarny Radziwitt (1515-1565). Kanclerz i marszatek ziemski Wielkiego Księstwa Litewskiego, wojewoda wileński, wyd. 2, Oświęcim 2014. 
„małego” Podlasia, Krzysztofie II Radziwille ${ }^{2}$, a także opracowanie o reformacji na Podlasiu ${ }^{3}$.

Geneza reformacji na Podlasiu

Podlasie jest obszarem pogranicznym, po białorusku zwanym Podlaszsza, po ukraińsku - Pidlaszszia, po litewsku - Palenke. Jeśli chodzi o etymologię polską, to Samuel Bogumił Linde wyjaśniał: „kraj bliski lasów" ", a więc zwracał uwagę na sąsiedztwo Puszczy Białowieskiej. Zygmunt Gloger zaś pisał: kraj „bliski Lachów”, „pod-lasze”, a zatem, tłumacząc pochodzenie nazwy, sugerował, że mamy do czynienia z krainą o mieszanym składzie narodowym, ale podporządkowaną przez „Lachów” i czynił aluzję do końca zasięgu etnicznego Polaków, a co za tym idzie także Rusinów czy Litwinów5. Ziemia podlaska od początków państwowości polskiej i ruskiej stała się obszarem ścierających się wpływów politycznych i co za tym idzie - religijnych ${ }^{6}$. Najważniejszym grodem, po zburzeniu pierwotnych, mazowieckich, w Zbuczu, Klukowiczach i Zajączkach w XI w. ${ }^{7}$, stał się Drohiczyn, gdzie - według ruskich latopisów - istniała prawosławna świątynia pw. Przeczystej Bogarodzicy ${ }^{8}$. Gdy na przełomie XII i XIII w., korzystając z rozbicia dzielnicowego Rusi, gród przejęli książęta mazowieccy, utrwaliły się tam rządy katolickie. Współistnienie obu nurtów chrześcijaństwa stało się faktem.

2 Zob. U. Augustyniak, Dwór i klientela Krzysztofa Radziwitta (1585-1640). Mechanizmy patronatu, Warszawa 2001.

3 Zob. A. Panasiuk, Reformacja na Podlasiu do potowy XVII wieku, Lublin 2004, mps pracy magisterskiej pod kier. prof. dr. hab. H. Gmiterka. Chciałbym w tym miejscu podziękować zarówno pracownikom Archiwum Uniwersytetu Marii Curie-Skłodowskiej, jak i autorce opracowania za udostępnienie mi maszynopisu książki.

4 B. S. Linde, Stownik języka polskiego, t. 4, Lwów 1858, s. 222.

5 Z. Gloger, Geografia historyczna ziem dawnej Polski, Kraków 1900, s. 201.

6 Według Antoniego Mironowicza początki „chrześcijaństwa na Białostocczyźnie wiążą się ściśle z Kościołem prawosławnym” (idem, $Z$ dziejów prawostawia na Białostocczyźnie, „Białoruskie Zeszyty Historyczne” [dalej: BZH], 10, 1998, s. 12), choć badacz przyznaje (ibidem, s. 14), że ostatecznie struktura kościelna ukształtowała się już w okresie przynależności Podlasia do Wielkiego Księstwa Litewskiego.

7 Por. D. Krasnodębski, Badania Instytutu Archeologii i Etnologii PAN na terenie woj. biatostockiego (podlaskiego) w latach 1990-2005, w: H. Karwowska, A. Andrzejewski, Stan badań archeologicznych na pograniczu polsko-biatoruskim od wczesnego średniowiecza po czasy nowożytne, Białystok 2006, s. 66, 74.

8 Por. T. Jasztołt, Fundacje kościelne na Podlasiu do końca XV wieku, w: Kościoty a państwo na pograniczu polsko-litewsko-biatoruskim. Źródta i stan badań, red. M. Kietliński, K. Sychowicz, W. Śleszyński, Białystok 2005, s. 21. 
W XIV w., w związku z powstaniem silnego państwa litewskiego (jeszcze pogańskiego), Podlasie weszło w skład Litwy, od 1413 r. stanowiło południowo-zachodnią część województwa trockiego. 29 sierpnia 1513 r. wielki książę litewski i król polski Zygmunt Stary polecił utworzenie odrębnego województwa podlaskiego. W 1566 r. na sejmie wileńskim wydzielono $\mathrm{z}$ województwa podlaskiego ziemie brzeską, kamieniecką i kobryńską, które wraz z księstwem turowsko-pińskim utworzyły województwo brzeskolitewskie (brześciańskie). Województwo podlaskie zmieniło przynależność na mocy aktu sejmowego z 5 marca 1569 r. (przywilej przywrócenia ziemi podlaskiej do Korony Polskiej), brześciańskie natomiast pozostało w granicach Wielkiego Księstwa Litewskiego. Ostatecznie „duże” Podlasie zostało zatem podzielone na „małe” Podlasie - z głównym grodem w Drohiczynie i Polesie - z siedzibą w Brześciu. Co oczywiste, im bardziej na wschód, tym rósł wpływ prawosławia ${ }^{9}$, na zachód zaś katolicyzmu. Przygotowując się do zawarcia unii polsko-litewskiej, wielki książę litewski i król polski Zygmunt August wydał w 1563 r. przywilej zrównujący politycznie oba wyznania ${ }^{10}$. W tym czasie wzrosły wpływy reformacyjne w Wielkim Księstwie Litewskim.

Idee religijne zainicjowane wystąpieniem Lutra znalazły tu posłuch najpierw pośród mieszczaństwa niemieckiego, podobnie jak na sąsiadującym z Litwą (i Podlasiem) Mazowszu ${ }^{11}$. Jeśli chodzi o całe Wielkie Księstwo, to pewien odsetek Niemców zamieszkiwał na Żmudzi, która na przełomie XIV i XV w. była pod panowaniem krzyżackim, oraz w stołecznym Wilnie. Właśnie do stolicy przybył Abraham Kulwieć, absolwent uniwersytetu w Wittenberdze (a także w Lipsku i Sienie, gdzie uzyskał doktorat z prawa), i w 1539 r. założył tam „szkołę biblijną” w celu „zreformowania chrześcijaństwa”. Nie utrzymał się jednak długo, z powodu szykan, i w 1542 r. wraz z kilkoma towarzyszami wyjechał do księcia pruskiego ${ }^{12}$.

9 Por. J. Hardziejeu, W kwestii stratygrafii spotecznej Grodna w pierwszej potowie XVI w., BZH, 16, 2001, s. 26-43.

10 Por. T. Kempa, Magnateria ruska wobec unii lubelskiej (1569), BZH, 16, 2001, s. 5-24.

11 Por. J. Mironczuk, Reformacja na Mazowszu Pótnocnym (diecezja ptocka), „Studia Theologica Pentecostalia”, 4, 2016, s. 74-79.

12 Por.: M. Kosman, Protestanci i kontrreformacja. $Z$ dziejów tolerancji w Rzeczypospolitej w XVI-XVIII wieku, Wrocław 1978, s. 51; S. Augusiewicz, J. Jasiński, T. Oracki, Wybitni Polacy w Królewcu. XVI-XX wiek, wstęp i red. J. Jasiński, Olsztyn 2005. 
Luteraninem w 1542 r. został też Jan Radziwiłł, młodszy brat przyszłego organizatora religii helweckiej na Litwie i Podlasiu - Mikołaja „Czarnego". Właśnie śmierć 35-letniego Jana we wrześniu 1551 r. (i kilka miesięcy wcześniej 30-letniej stryjecznej siostry Barbary, żony Zygmunta Augusta) miała ostatecznie skłonić Mikołaja Radziwiłła do religijnej determinacji:

Śmierć bliskich osób zmusiła kanclerza Wielkiego Księstwa Litewskiego, by zastanowić się nad sensem życia i [- - ] wreszcie podjąć decyzję, by pójść za Chrystusem. Podjęciu tej decyzji sprzyjały stałe kontakty Radziwiłła "Czarnego" z księciem pruskim Albrechtem Hohenzollernem, który sam przeszedł podobną drogę i w okresie czterdziestu lat był jednym z liderów reformacji w Europie Wschodniej ${ }^{13}$.

Należy jednak w tym miejscu zauważyć, pomijając już fakt nie najlepszych relacji Mikołaja „Czarnego” z Barbarą, że zadziałał jeszcze inny czynnik: po uzyskaniu od króla (który nawet skłaniał się początkowo ku reformacji) najwyższych tytułów Mikołaj niczym już "nie ryzykowal" 14 .

Mikołaj Radziwiłł był w połowie XVI w. najpotężniejszym magnatem w Wielkim Księstwie Litewskim: łączył stanowiska marszałka wielkiego, kanclerza wielkiego i wojewody wileńskiego, z rąk cesarza Karola V otrzymał tytuł książęcy, a poprzez bliską znajomość i rodzinne koligacje stał się głównym doradcą króla. Wspomniane tragiczne doświadczenia z $1551 \mathrm{r}$. przyczyniły się do tego, że ujawnił swoje przekonania religijne, organizując od połowy 1552 r. w Brześciu nad Bugiem pierwszy w Wielkim Księstwie Litewskim zbór ${ }^{15}$ - początkowo o nieokreślonej konfesji protestanckiej, dopiero po korespondencji z Kalwinem zorientowany na kierunek ewangelicko-reformowany. Zdecydował się też na walkę z „papizmem”, organizując nowe zbory, a także zmieniając w swoich dobrach (m.in. w Nieświeżu, Klecku, Mordach) kościoły na zbory kalwińskie. Ponadto nakazał utworzenie drukarni w Brześciu, której głównym osiągnięciem

13 A. I. Bokun, Mikataj Radziwit Czorny: żyćcio i pamiać, w: Jevanhelskaja Carkva Bietarusi: historyja i suczasnasć. Zbornik materyjatau II Miżnarodnaj navukova-praktycznaj kanfierencyi (Minsk, 5 snieżnia 2015 h.), red. P. I. Asienienka, J. A. Baczyszcza, A. I. Bokun, L. I. Michovicz, A. U. Unuczak, Minsk 2016, s. 9 (jeżeli nie zaznaczono inaczej, tłum. pochodzą od autora).

14 J. Jasnowski, Mikotaj Czarny Radziwitt, s. 36-41, 148-151.

15 Por. ibidem, s. 151. Wówczas na dwór „Czarnego” przybył Szymon Zacjusz, który został kaznodzieją zboru. 
było wydanie w 1563 r. polskiego przekładu Biblii (chodzi o tzw. Biblię Brzeską inaczej zwaną Radziwiłłowska). Jednak po rozłamie w łonie Kościoła ewangelicko-reformowanego i wyłonieniu się „zboru mniejszego" (antytrynitarnego) ten wielki opiekun i propagator reformacji stanął ostatecznie po stronie arian ${ }^{16}$.

Za przykładem Mikołaja „Czarnego” w tworzeniu zborów reformowanych (i, później, ariańskich) poszli nie tylko Radziwiłłowie, ale także inne rody w Wielkim Księstwie. Jak pisze Marceli Kosman, „W stosunkowo krótkim czasie powstało około 200 zborów [- - ] po części z zabranych kościołów katolickich w dobrach prywatnych, po części zaś dzięki zorganizowaniu od podstaw nowych parafii [- - ]. W szczytowym okresie reformacji, pod koniec XVI w., pod względem liczbowym - wydaje się - zbory przeważały nad parafiami katolickimi w diecezjach litewskich"17. Przyczyny tak szybkiego rozwoju wyznań protestanckich w Wielkim Księstwie Litewskim zostały już wystarczająco, jak się wydaje, naświetlone przez historiografię. Wśród najważniejszych wymienić trzeba m.in. świeżość, czyli nieugruntowanie katolicyzmu na Litwie, rywalizację z prawosławiem, poszukiwanie przez Litwinów „własnej” religii, atrakcyjność oświatowa i wydawnicza wyznań reformacyjnych ${ }^{18}$. Interesujący i wymowny w tym kontekście jest list wybitnego przedstawiciela „różnowierstwa”, Szymona Budnego, dotyczący stosunków wyznaniowych w Wielkim Księstwie Litewskim:

Niektórym trzeba wydzierać zabobony papiestwa, u innych wykorzenić prastare bałwochwalstwo ludowe [- ]. U innych znowu nam trzeba walczyć z naukami Greków, w których rękach znajdują się kościoły na Rusi ${ }^{19}$.

Prawosławie, poza konfrontacją z wyznaniami reformacyjnymi, zetknęło się pod koniec XVI w. także z problemem unityzmu, co jeszcze bardziej różnicowało strukturę wyznaniową terenów pogranicza ${ }^{20}$.

16 Por. ibidem, s. 170-174, 289-293.

17 M. Kosman, Protestanci i kontrreformacja, s. 20.

18 Por. ibidem; a z nowszych ujęć: M. Liedke, Od prawostawia do katolicyzmu. Ruscy możni i szlachta Wielkiego Księstwa Litewskiego wobec wyznań reformacyjnych, Białystok 2004.

19 M. Kosman, Historia Biatorusi, Wrocław 1979, s. 131.

20 Zob.: J. Maroszek, Dziedzictwo unii kościelnej w krajobrazie kulturowym Podlasia: 1596-1996, Białystok 1996; A. Mironowicz, Kościót prawostawny i unicki w Rzeczypospolitej $w$ latach 1596-1648, BZH, 5, 1996, s. 23-55; D. Michaluk, O możliwościach badań struktury etnicznej Podlasia $w$ XVI wieku, BZH, 17, 2002, 
Zbory na obszarze dystryktu podlaskiego Powstanie pierwszego zboru protestanckiego w Brześciu w 1552 r. rozpoczęło okres reformacji w Wielkim Księstwie. Ponieważ proces ten nastąpił z pewnym opóźnieniem w stosunku do zborów małopolskich czy wielkopolskich, Litwini wykorzystywali rozwiązania zastosowane przez swoich współwyznawców z Korony. Współpraca przyniosła wykształcenie się w Rzeczypospolitej trzech samodzielnych i równorzędnych prowincji, zwanych jednotami: wielkopolskiej, małopolskiej oraz litewskiej. Ich przedstawiciele w zależności od potrzeb spotykali się na synodach generalnych. $\mathrm{Na}$ mocy uchwały konwokacji z Włodawy z 1634 r. zarządcy prowincji i dystryktów (superintendenci) mieli corocznie spotykać się kolejno w: Toruniu (prowincja wielkopolska), Orli (Jednota Litewska), Włodawie (Małopolska) ${ }^{21}$. Jednota Litewska w 1560 r. podzieliła prowincję na dwa dystrykty ${ }^{22}$. Później doszło do dalszego podziału i krystalizacji struktury Kościoła ewangelicko-reformowanego. Przywoływany już M. Kosman zauważał:

Litwa [- - ] już zapewne od ósmego dziesięciolecia dzieliła się na sześć dystryktów [- ]. Na ich czele stali superintendenci. Władze dla dystryktu stanowił jego synod, który jednak przy daleko posuniętej centralizacji władzy podejmował decyzje wyłącznie w sprawach drobniejszej wagi. Zasadnicze sprawy natomiast były rozpatrywane na dorocznych sesjach synodu prowincjonalnego $\mathrm{w}$ Wilnie. Tam zapadały m.in. rozstrzygnięcia w sprawach kadrowych dla wszystkich zborów w Wielkim Księstwie, dystrykty zajmowały się nimi jedynie doraźnie. Do połowy XVII w. liczba dystryktów nie uległa zmniejszeniu ${ }^{23}$.

W województwie podlaskim („małym” Podlasiu), mimo że po unii lubelskiej znalazło się ono w Koronie, właścicielami wielu dóbr byli Radziwiłłowie na Birżach i Dubinkach, kalwiniści. Dystrykt podlaski obejmował więc, jak wspomniano, zarówno litewskie województwo brześciańskie, jak i koronne podlaskie.

s. 57-72; K. Śleszyński, Struktura narodowościowa i wyznaniowa Zabtudowa w XVII wieku, BZH, 28, 2007, s. 23-34.

21 Zob. Wstęp, w: Akta synodów prowincjonalnych Jednoty Litewskiej 1626-1637, wstęp i oprac. M. Liedke, P. Guzowski, Warszawa 2011, s. IX-X.

22 Zob. M. Liedke, Dystrykt podlaski w strukturze Kościota ewangelicko-reformowanego $w$ Wielkim Księstwie Litewskim do końca XVIII wieku - źródta i stan badań, w: Kościoty a państwo na pograniczu polsko-litewsko-biatoruskim, s. 68.

23 M. Kosman, Litewska jednota ewangelicko-reformowana od potowy XVII $w$. do 1939 r., Opole 1986, s. 8. 
Analizując dane zawarte w tabeli 1 , można zauważyć dominującą rolę Radziwiłłów w organizowaniu zborów w dystrykcie podlaskim. Niewątpliwie na pierwszy plan wysuwał się Mikołaj „Czarny”, który przyczynił się do powstania na omawianym obszarze nie tylko kalwinizmu, ale i heretyckiego dla tego wyznania arianizmu - konfesji tej pozostał wierny, umierając jeszcze w sile wieku.

Poza nim warto zwrócić uwagę także na działalność bratanka „Czarnego”, Krzysztofa Mikołaja „Pioruna” (który, wspierając kalwinizm, zwalczał „odszczepieństwo” ariańskie) i Krzysztofa II (syna „Pioruna”, a ojca Janusza), organizatora zborów w Zabłudowie i Orli, a także porządkującego sytuację $\mathrm{w}$ Węgrowie, a więc w miejscowościach położonych na właściwym Podlasiu. Opiekunem arian okazał się zaś starosta żmudzki i kasztelan wileński Jan Kiszka, syn Anny z Radziwiłłów. Po jego śmierci bracia polscy nie mieli już jednak tak możnych protektorów i mogli liczyć jedynie na średniozamożną szlachtę (najpierw Jerzego Illinicza, a potem Pawła Orzechowskiego), która patronowała im w swoich majątkach.

Ciężki cios zadał protestantom na obszarze dystryktu podlaskiego syn Mikołaja „Czarnego”, też wojewoda wileński, Mikołaj Krzysztof „Sierotka”, który z wielką gorliwością, jakby chcąc zmazać winy ojca, wziął się za zwalczanie „sekty ariańskiej”, a nawet swoją żonę Elżbietę Wiśniowiecką nawrócił na katolicyzm ${ }^{24}$.

Większość zborów kalwińskich przetrwała okres początkowej kontrreformacji, ale od połowy XVII w. zderzyła się - w obliczu nieustannych wojen prowadzonych przez Rzeczpospolitą z innowierczymi przeciwnikami - z problemami własnej organizacji kościelnej oraz rosnącą nietolerancją i agresją katolickiej większości. Zdaniem M. Kosmana: „lata 1656-61 stanowiły przerwę w obradach synodalnych, spowodowaną sytuacją polityczną Rzeczypospolitej [- - ]. w następnych latach [z powodu straszliwego zniszczenia Wilna - J.M.] zwoływano jedynie konwokacje w Kiejdanach [- - ]. Po śmierci księcia Bogusława [w 1669 r. - J.M.] kalwini zdali sobie jednak sprawę, że i Kiejdany nie gwarantują bezpieczeństwa. Dlatego nauczeni smutnym doświadczeniem [spalenie zboru i archiwum wileńskiego w lipcu 1611 r. - J.M.] postanowili [- - ] ulokować swe archiwum poza stolicą" 25 - najpierw w Kiejdanach (1673), potem Birżach (1679) i ostatecznie w Królewcu (1699), gdzie dotrwało do zaborów.

24 Zob. idem, Protestanci i kontrreformacja, s. 58.

25 Idem, Litewska jednota ewangelicko-reformowana, s. 33. 
Tabela 1. Zbory na terenie dystryktu podlaskiego

\begin{tabular}{|c|c|c|}
\hline $\begin{array}{c}\text { Miejscowość, } \\
\text { konfesja }\end{array}$ & $\begin{array}{c}\text { Data i okoliczności } \\
\text { powstania }\end{array}$ & $\begin{array}{l}\text { Data i okoliczności } \\
\text { rozwiązania }\end{array}$ \\
\hline $\begin{array}{l}\text { Brześć, } \\
\text { kalwiński }\end{array}$ & $\begin{array}{l}\text { 1552-1553, Mikołaj Radziwiłł } \\
\text { "Czarny” tworzy zbór (z „mini- } \\
\text { strem helweckim” Szymonem Za- } \\
\text { cjuszem) i drukarnię }\end{array}$ & $\begin{array}{l}\text { na początku lat } 60 \text {. fundatora do } \\
\text { arianizmu przekonał Piotr z Go- } \\
\text { niądza }\end{array}$ \\
\hline $\begin{array}{l}\text { Mordy (ziemia } \\
\text { drohicka), } \\
\text { kalwiński/ } \\
\text { ariański }\end{array}$ & $\begin{array}{l}\text { 1553-1554, Mikołaj Radziwiłł } \\
\text { „Czarny” usunął miejscowego } \\
\text { proboszcza i na jego miejsce wpro- } \\
\text { wadził „ministra helweckiego”; po } \\
\text { synodzie ariańskim tam (1563) } \\
\text { nakazał zamianę na ministra } \\
\text { ariańskiego }\end{array}$ & $\begin{array}{l}\text { 1571, Mikołaj Krzysztof Radzi- } \\
\text { wiłł „Sierotka”, syn Mikołaja } \\
\text { „Czarnego”, wrócił do katolicy- } \\
\text { zmu, Mordy przeszły w ręce Paw- } \\
\text { ła Ciecierskiego, zbór zamknięto, } \\
\text { przywrócono parafię katolicką }\end{array}$ \\
\hline $\begin{array}{l}\text { Biała } \\
\text { (Podlaska), } \\
\text { kalwiński/ } \\
\text { ariański }\end{array}$ & $\begin{array}{l}\text { około } 1555 \text {, właściciel miasta Je- } \\
\text { rzy Illinicz, przyjaciel fundatora } \\
\text { Mikołaja Radziwiłła "Czarnego", } \\
\text { zgodził się na „prowadzenie tu } \\
\text { propagandy wyznaniowe”, mini- } \\
\text { strem został Hieronim Piekarski }\end{array}$ & $\begin{array}{l}\text { 1571, Mikołaj Krzysztof Radzi- } \\
\text { wiłł „Sierotka” wrócił do katoli- } \\
\text { cyzmu, likwidacja zboru i szkoły } \\
\text { (katechistą był m.in. Jan Falko- } \\
\text { niusz) }\end{array}$ \\
\hline $\begin{array}{l}\text { Węgrów, } \\
\text { kalwiński }\end{array}$ & $\begin{array}{l}\text { 1558, przejęcie kościoła i pleba- } \\
\text { nii katolickiej przez Annę Kiszkę } \\
\text { z Radziwiłłów, usunięcie ks. Wa- } \\
\text { lentego Suchodolskiego, w latach } \\
\text { 1630-1634 budowa nowego bu- } \\
\text { dynku zborowego }\end{array}$ & $\begin{array}{l}1630 \text { - Krzysztof II Radziwiłł } \\
\text { zwrócił świątynię katolikom; } \\
1678 \text { - spalenie budynku zbo- } \\
\text { rowego (przez zakonników refor- } \\
\text { matów?); } 1679 \text { - budowa nowe- } \\
\text { go budynku; } 1779 \text { - rozwiązanie } \\
\text { zboru }\end{array}$ \\
\hline $\begin{array}{l}\text { Sokołów, } \\
\text { kalwiński }\end{array}$ & $\begin{array}{l}\text { po } 1563 \text { założenie zboru przez } \\
\text { Annę Kiszkę z Radziwiłłów }\end{array}$ & 1590, likwidacja zboru \\
\hline $\begin{array}{l}\text { Węgrów, } \\
\text { ariański }\end{array}$ & $\begin{array}{l}\text { 1569, Jan Kiszka zamienił zbór } \\
\text { kalwiński na ariański, kaznodzie- } \\
\text { jami byli m.in. Marcin Krowicki } \\
\text { i Piotr z Goniądza }\end{array}$ & $\begin{array}{l}\text { 1592, Krzysztof Radziwiłł „Pio- } \\
\text { run” przepędził arian }\end{array}$ \\
\hline $\begin{array}{l}\text { Kostrów } \\
\text { k. Węgrowa, } \\
\text { ariański }\end{array}$ & $\begin{array}{l}\text { lata 60. XVI w., ufundowany } \\
\text { przez Jana Kiszkę }\end{array}$ & $\begin{array}{l}\text { koniec XVI w., po śmierci fun- } \\
\text { datora }\end{array}$ \\
\hline $\begin{array}{l}\text { Sidra, } \\
\text { kalwiński }\end{array}$ & $\begin{array}{l}\text { lata 60. XVI w., ufundowany } \\
\text { przez Ostafija [może Ostafiego?] } \\
\text { Wołłowicza }\end{array}$ & $\begin{array}{l}\text { 1839, zamknięcie zboru z powo- } \\
\text { du braku wiernych }\end{array}$ \\
\hline $\begin{array}{l}\text { Rusków } \\
\text { (w parafii } \\
\text { Sarnaki), } \\
\text { kalwiński }\end{array}$ & $\begin{array}{l}\text { 1580, ufundowany przez rodzinę } \\
\text { Raczków herbu Ostoja, sędziów } \\
\text { i wojskich ziemi bielskiej }\end{array}$ & $\begin{array}{l}\text { 1614, minister Gutowski donosi } \\
\text { o upadku z powodu braku fun- } \\
\text { duszy na utrzymanie zboru }\end{array}$ \\
\hline
\end{tabular}




\begin{tabular}{|c|c|c|}
\hline $\begin{array}{c}\text { Miejscowość, } \\
\text { konfesja }\end{array}$ & $\begin{array}{c}\text { Data i okoliczności } \\
\text { powstania }\end{array}$ & $\begin{array}{c}\text { Data i okoliczności } \\
\text { rozwiązania }\end{array}$ \\
\hline $\begin{array}{l}\text { Siemiatycze, } \\
\text { kalwiński }\end{array}$ & $\begin{array}{l}\text { 1588, Krzysztof Mikołaj Radzi- } \\
\text { wiłł „Piorun” uzyskał od Tęczyń- } \\
\text { skich dobra i ufundował zbór }\end{array}$ & $\begin{array}{l}\text { 1599, Siemiatycze weszły w skład } \\
\text { posagu Elżbiety Radziwiłłówny } \\
\text { poślubiającej Lwa Sapiehę, który } \\
\text { polecił rozebranie stojącego } \\
\text { w pobliżu rynku zboru i istnie- } \\
\text { jącej przy nim prawdopodobnie } \\
\text { szkoły ewangelickiej }\end{array}$ \\
\hline $\begin{array}{l}\text { Sielec*, } \\
\text { kalwiński }\end{array}$ & $\begin{array}{l}\text { 1589, zbór założył Krzysztof Mi- } \\
\text { kołaj Radziwiłł „Piorun”, posługę } \\
\text { ministerialną spełniali tu m.in.: } \\
\text { W. Petrowiusz, Łukasz Kozmi- } \\
\text { niusz, Adam Roszecki }\end{array}$ & 1745 \\
\hline $\begin{array}{l}\text { Świsłocz*, } \\
\text { kalwiński }\end{array}$ & $\begin{array}{l}\text { pod koniec XVI w., po przejęciu } \\
\text { kościoła katolickiego, w } 1624 \text { mi- } \\
\text { nistrem był Korzepia }\end{array}$ & $\begin{array}{l}\text { 1630, katolicy odzyskali kościół, } \\
\text { zbór upadł pod koniec XVII w. }\end{array}$ \\
\hline Suraż, ariański & $\begin{array}{l}\text { 1590, pod opieką starosty sura- } \\
\text { skiego Pawła Orzechowskiego }\end{array}$ & $\begin{array}{l}\text { 1612, zbór przestał istniał po } \\
\text { śmierci Pawła Orzechowskiego }\end{array}$ \\
\hline $\begin{array}{l}\text { Pietuchów*/ } \\
\text { Izabelin, } \\
\text { kalwiński }\end{array}$ & $\begin{array}{l}\text { pod koniec XVI w., } 1612-\text { mi- } \\
\text { nister Hazler, } 1638-\text { minister } \\
\text { Biskupski, } 1778-\text { kolejne erygo- } \\
\text { wanie zboru przez Jana Grabow- } \\
\text { skiego }\end{array}$ & $\begin{array}{l}\text { 1941, budynek zboru w Izabeli- } \\
\text { nie przejęli katolicy }\end{array}$ \\
\hline $\begin{array}{c}\text { Dokudów* } \\
\text { (Lewkowo), } \\
\text { kalwiński } \\
\end{array}$ & $\begin{array}{l}\text { pod koniec XVI w., w } 1631 \text { pa- } \\
\text { tronką zboru była Dorota Tysz- } \\
\text { czyna }\end{array}$ & dotrwał do XIX w. \\
\hline $\begin{array}{l}\text { Niepokojczyce } \\
\text { k. Brześcia, } \\
\text { kalwiński }\end{array}$ & 1597, budowa zboru & $\begin{array}{l}\text { w okresie międzywojennym była } \\
\text { tu filia zboru w Raśnej, } 1960 \text { - } \\
\text { utrata budynku }\end{array}$ \\
\hline $\begin{array}{l}\text { Horodyszcze, } \\
\text { kalwiński }\end{array}$ & $\begin{array}{l}\text { zbór wybudował właściciel Trojan } \\
\text { Piotrowski, na synodzie w } 1637 \\
\text { postanowiono: „do zboru horody- } \\
\text { skiego mają zjeżdżać bliższy mini- } \\
\text { strowie” }\end{array}$ & $\begin{array}{l}\text { w XVIII w. zbór przebudowany } \\
\text { na kościół katolicki }\end{array}$ \\
\hline $\begin{array}{c}\text { Stara Wieś } \\
\text { (Jachimowicze), } \\
\text { kalwiński } \\
\end{array}$ & $\begin{array}{l}\text { przed } 1625 \text { (zachowany inwentarz } \\
\text { zboru), fundacja Rayskich }\end{array}$ & $\begin{array}{l}\text { po } 1661 \text { (zachowany inwentarz } \\
\text { zboru) }\end{array}$ \\
\hline $\begin{array}{l}\text { Zabłudów, } \\
\text { kalwiński }\end{array}$ & $\begin{array}{l}\text { 1608, ufundował Krzysztof II Ra- } \\
\text { dziwiłł, zbór uposażony placami } \\
\text { w mieście i folwarkiem Rafałówka }\end{array}$ & $\begin{array}{l}\text { 1858, ostatni minister Jan Man- } \\
\text { dzelowski przeniósł się do Izabe- } \\
\text { lina na Grodzieńszczyźnie }\end{array}$ \\
\hline $\begin{array}{c}\text { Orla, } \\
\text { kalwiński }\end{array}$ & $\begin{array}{l}15 \text { XII } 1611 \text {, wzmianka o pozy- } \\
\text { skanym drewnie „tak na zbór, iako } \\
\text { na dworną potrzebę”, pod patro- } \\
\text { natem Krzysztofa Radziwiłła }\end{array}$ & $\begin{array}{l}1704 \text { - brak stałego ministra, } \\
1770 \text { - rozwiązanie } \mathrm{z} \text { powodu } \\
\text { braku wiernych }\end{array}$ \\
\hline
\end{tabular}




\begin{tabular}{|c|l|l|}
\hline $\begin{array}{c}\text { Miejscowość, } \\
\text { konfesja }\end{array}$ & \multicolumn{1}{|c|}{$\begin{array}{c}\text { Data i okoliczności } \\
\text { powstania }\end{array}$} & \multicolumn{1}{|c|}{$\begin{array}{c}\text { Data i okoliczności } \\
\text { rozwiązania }\end{array}$} \\
\hline $\begin{array}{c}\text { Nurzec, } \\
\text { kalwiński }\end{array}$ & $\begin{array}{l}\text { 1631, ufundował przez Piotra Ko- } \\
\text { chlewskiego, sędziego brzeskiego }\end{array}$ & $\begin{array}{l}\text { 1745, stał się filią zboru w Jam- } \\
\text { nie }\end{array}$ \\
\hline $\begin{array}{c}\text { Jamno, } \\
\text { kalwiński }\end{array}$ & $\begin{array}{l}\text { 1643 (pierwsza wzmianka o zbo- } \\
\text { rze: w Brześciu jezuici zamordo- } \\
\text { wali ministra Stulichusa z Jamna), } \\
\text { fundacja Piekarskich }\end{array}$ & dotrwał do XIX w. \\
\hline $\begin{array}{c}\text { Węgrów, } \\
\text { luterański }\end{array}$ & $\begin{array}{l}\text { 25 VI 1650, Bogusław Radziwiłł } \\
\text { nadał luteranom warszawskim, } \\
\text { pozbawionym prawa do odpra- } \\
\text { wiania publicznych nabożeństw, } \\
\text { przywilej „dozwalający odbywać } \\
\text { nabożeństwa w kościele węgrow- } \\
\text { skim” (kalwińskim) }\end{array}$ & $\begin{array}{l}\text { parafia przetrwała, mimo wysie- } \\
\text { dlenia niemal wszystkich para- } \\
\text { fian Niemców w 1945 }\end{array}$ \\
\hline
\end{tabular}

Legenda: * - zbór zmienił przynależność dystryktową, przyłączony do dystryktu nowogródzkiego, np. zbór w Dokudowie w 1653 r. „dla zbytniej od superintendenta rezydencji odległości"; Akta synodów prowincjonalnych Jednoty Litewskiej 1638-1655, wstęp i oprac. M. Liedke, P. Guzowski [w druku, dziękuję M. Liedke za udostępnienie wskazanego cytatu].

Źródło: SGKP, 6, 1885, s. 676; J. Łukaszewicz, Dzieje kościołów wyznania helweckiego $w$ dawnej Litwie, t. 2, Poznań 1842, s. 69; E. Bagińska, Działalność religijna Radziwiłłów birżańskich $w$ dobrach podlaskich $w$ XVII wieku, „Studia Podlaskie”, 12, 2002, s. 205-228; A. Panasiuk, Reformacja na Podlasiu do połowy XVII wieku, Lublin 2004, mps pracy magisterskiej pod kier. prof. dr. hab. H. Gmiterka; Akta synodów prowincjonalnych Jednoty Litewskiej 1626-1637, wstęp i oprac. M. Liedke, P. Guzowski, Warszawa 2011; M. Sierba, Kalwiński zbór orlański w XVII wieku, BZH, 44, 2015, s. 46.

Ciężkie chwile w tym okresie przeżywał zbór stołeczny, a jego sytuację tak podsumował M. Kosman:

Celem zainspirowanego przez jezuitów tumultu z 1682 r. było wyrugowanie ewangelików reformowanych nawet spoza murów Wilna, tym samym poprzez zniszczenie najsilniejszej gminy wyznaniowej zadanie śmiertelnego ciosu całej Jednocie. Sięganie do wzorów polskich jeszcze z poprzedniego oraz XVII stulecia (Kraków, Poznań, Lublin, Raków) mogło czynić takie zamierzenie dosyć realnym. Zapomniano jednak, że Wielkie Księstwo rządzi się innymi prawami niż Korona ${ }^{26}$.

Kalwinistom udało się, co prawda, odbudować zniszczony zbór, jednak poczucie zagrożenia pozostało i nie zwoływali już synodów do Wilna, ale zbierali się w prywatnych dobrach Radziwiłłów.

26 Ibidem, s. 34. 
Co do sytuacji zborów całej Jednoty Litewskiej, w tym dystryktu podlaskiego, badacz reformacji w Wielkim Księstwie Litewskim zauważa:

Po wojnach miała sens odbudowa jedynie tych placówek, do których niekwestionowane prawo mieli protestanci. Natomiast kiedy w grę wchodziła świątynia zabrana wprost katolikom, czy nawet gruntownie przebudowana, a wówczas pozostająca $\mathrm{w}$ ruinie, brano pod uwagę raczej możliwość pozostawienia jej w aktualnym stanie (niech zabierają katolicy) i wystawienia w innym - już bezpiecznym - miejscu nowego domu modlitwy ${ }^{27}$.

W porównaniu z prowincjami Kościoła ewangelicko-reformowanego w Małopolsce i Wielkopolsce Jednota Litewska dotrwała do ustawy tolerancyjnej 1767-1768 r. w zdecydowanie najlepszym stanie, dzieliła się bowiem na pięć dystryktów, a mieściło się w nich w sumie 38 zborów ${ }^{28}$.

Protekcja Radziwiłłów nad wiernymi

protestanckimi

Względnie dobre położenie średniozamożnej i uboższej szlachty, a zwłaszcza duchownych protestanckich w dobie kontrreformacji w Wielkim Księstwie Litewskim oraz na pograniczu podlaskim było związane z protekcją potężnych Radziwiłłów ${ }^{29}$, którzy, co oczywiste, mieli także wielki wpływ na obsadę stanowisk kościelnych.

27 Zob. ibidem, s. 37.

28 Prowincje małopolska i wielkopolska były jednodystryktowe, $\mathrm{z}$ - odpowiednio - 13 i 9 zborami; szerzej na ten temat zob. M. Kosman, Protestanci i kontrreformacja, s. 37-38.

29 AGAD, AR, dz. VIII, sygn. 655, Akta uposażenia przez Radziwiłłów zboru ewangelickiego w Zabłudowie 1611-1774, s. 1, List Krzysztofa Radziwiłła do starosty Gładowskiego, 5 VII 1611 r.: „Rozkazujęć, abyś ordinari ksiedzu gutowskiemu [- ], zabłudowskiemu 3 gumna mego orleńskie według listu jemu ode mnie na to danego, krom gotowych pieniędzy"; ibidem, s. 7, Rozkaz Bogusława Radziwiłła, księcia na Birżach, 17 IX 1661 r.: „Urodzonemu Panu Mikołajowi Porębskiemu, słudze memu i staroście orleńskiemu [- ]. Ponieważ ks. kaznodzieja ordynowany jest do zboru orleńskiego i zabłudowskiego, tedy mieć po nas chcę, abyście mu [...] co rok dawali zł 150"; ibidem, s. 15, Regestr Jurgieltów, myta, ordinarii które co roku wydawane bydź maią w Zabłudowie 1685: „Jurgielta Jmości Ksiedzu pieniądze i żyta szanków 14, jęczmienia 9, prosa 3, grochu 1, gryki”. Krzysztof „Piorun” Radziwiłł, syn Mikołaja „Rudego”, kupił Zabłudów, a poprzez małżeństwo wszedł w posiadanie Orli i Węgrowa; zob. E. Bagińska, Patronat Radziwittów birżańskich na Podlasiu w XVII w., „Białostocczyzna”, 4, 1994, s. 19. W cytowanych źródłach zmodernizowano ortografię i interpunkcję. 
Szczególną troską „,zządu koło zborów” cechował się Krzysztof II Radziwitł, wnuk Mikołaja „Rudego” ${ }^{30}$. Zachował się interesujący list podsędkowej Anny Skromowskiej, wdowy (,w tem mojem smętku po zejściu <Z> świata miłego małżonka mego") po zarządcy dóbr orlańskich. Przypominała ona, że „Jaśnie Oświecone Wielmożne Książę [- - ] w dobrach swoich Podlaskich ma Plebanię Węgrowską", wówczas opuszczoną, i informowała, że „po miłem małżonku” ma syna, a tego „Pan Bóg z wolej swojej świętej powołać raczył do stanu duchownego”. Zwracała się zatem z prośbą: „mój miłościwy Panie, proszę, racz z Swej Miłościwej łaski przyłożyć się żądaniem swem do [- - ] Wileńskiego Pana mego Miłościwego [chodzi zapewne o superintendenta wileńskiego - J.M.] o tę to plebanię synowi memu". W razie spełnienia życzenia wdowa zapewniała: ,już ze wszystkiego byłabym kontenta [- - ], Miłościwy Pan wieczną pamiątkę zasług [- - ] małżonka mego [poczyniłby - J.M.], za co ja i ten syn mój za dobre zdrowie [- - ] Miłościwych Panów Pana Boga prosić"31.

Do wspomnianej Orli na Podlasiu, gdzie Krzysztof Radziwiłł ufundował w drugim dziesięcioleciu XVII w. zbór reformowany (zob. tab. 1), wojewoda bełski Rafał Leszczyński skierował w 1627 r. syna kasztelana rozpierskiego Samuela Sładkowskiego. O całej sprawie nowy zarządca Orli, Stanisław Kurosz, donosił swemu patronowi:

Urodził się ten Pan Składkowski młody z rodziców obojga ewangelików ewangelikiem, w tymże ewangelickim nabożeństwie wychowany. Rodzice ci po tym odstąpili od nabożeństwa ewangelickiego do papiestwa. Tego po tym synu, aby to uczynił, chcieli [- $[$, aby go od tego nabożeństwa ewangelickiego jako małe dzieci za sobą pociągneli, już go obietnicami wielkimi łaski i miłości swej przywodząc, to rodzice ci są majętni i pieniężni bardzo, już prośbami i biciem okrutnym. Na ostatek, widząc go być tak stanowczym, ręką swą chciał go już ociec zabić. Widząc owe nieprzelewki, nie mając ratunku ni skąd i pociechy [- ] pozwolił na to [- - , że się spowiadał i komunikował ${ }^{32}$.

Ale i to nie zadowoliło rodziców neofitów, gdyż aby „go mieć doskonalszym katolikiem rodzice ci chcieli $[--]$, aby koniecznie

30 Por. U. Augustyniak, Dwór i klientela Krzysztofa Radziwitta, s. 46.

31 AGAD, AR, dz. XXIII, t. 105, p. 2 (Rozmaitości orlańskie), s. 16, Pismo podsędkowej Anny Skromowskiej do Krzysztofa Radziwiłła na Birżach i Dubinkach, hetmana polnego litewskiego, 14 VI 1619 r.

32 AGAD, AR, dz. V, sygn. 8080, Kurosz Stanisław, zarządca Orli 1620-1628, k. 154-158, Pismo zarządcy Orli do JO Mksięcia, 28 VII 1627 r. 
księdzem był i habit kiedy by oblókł”. Młody kasztelanic, zostawszy księdzem, ostatecznie zbuntował się jednak i pragnął „habit ten przeklęty porzucić się jednak i tam się udać, gdzie by mógł w wolnym sumieniu Bogu służyć, by w religijej ewangelickiej dni swoje trawić"33. Przebywając w Lublinie w otoczeniu biskupa, dopytywał o ewangelików i uzyskał pomoc wspomnianego wojewody. Brak dodatkowych źródeł nie pozwala na prześledzenie dalszych losów kasztelanica Sładkowskiego.

Kalwińscy Radziwiłłowie, będąc mniej żarliwymi od swoich predykantów, pozwalali przebywać w swoich dobrach także arianom. Bracia polscy w XVII w. złagodzili swoją nieprzejednaną wobec urzędów czy wojen postawę, stąd, nieuznawani przez innych protestantów, odwdzięczali się swoim protektorom wierną służbą. Po Surażu (zob. tab. 1) pojawili się w Dojlidach, gdzie w 1629 r. sławny Samuel Przypkowski wziął w dzierżawę od Krzysztofa Radziwiłła miejscowy folwark za 1300 zł. W 1645 r. Janusz Radziwiłł, syn Krzysztofa, oddał Dojlidy w dzierżawę Krzysztofowi Arciszewskiemu, już wtedy kalwiniście, za 5 tys. dukatów, a ten ostatni w 1647 r. za taką sumę puścił ją arianinowi Samuelowi Mierzeńskiemu. Do Dojlid czasowo przybył nawet wybitny poeta Zbigniew Morsztyn ${ }^{34}$. Dzierżawcą zaś Białostoczka i Kurian został około 1640 r. wspomniany Stanisław Kurosz. Już za czasu jego pobytu w Orli odbywały się tam nabożeństwa ariańskie ${ }^{35}$.

Po wydaniu edyktu o wygnaniu arian w 1658 r. i po jego ponowieniu z zastrzeżeniem, że bracia polscy mogą pozostać jedynie po przejściu wyłącznie na katolicyzm, do wspomnianych majątków zarządzanych przez arian zaczęli przybywać zagrożeni współwyznawcy, osiągając wraz z czeladzią liczbę około „pół setki” ${ }^{36}$. Mimo że termin wykonania konstytucji upływał 10 lipca 1660 r., to arianie, licząc na niewykonanie postanowień, pozostawali na miejscu. Bronił ich zresztą na obradach sejmowych w kwietniu 1661 r. książę Bogusław, zarzucając posłom katolickim, że chcieliby, by wszyscy ewangelicy „z Polski migrare”37.

Przeciwko arianom z dóbr zabłudowskich zdecydowanie wystąpił tamtejszy pleban Faustyn Wieczorkowski, który został - z różnych

33 Ibidem.

34 Zob. J. Tazbir, Bracia polscy w Zabtudowie i Dojlidach, OiRwP, 52, 2008, s. 6-8.

35 Por. ibidem, s. 9.

36 Por. ibidem, s. 12.

37 Ibidem, s. 13. 
powodów, nie tylko wyznaniowych - delatorem wobec arian i ich protektora księcia Bogusława. Dzięki staraniom księdza Wieczorkowskiego w czerwcu 1662 r. oblatowano pozwy w Grodnie przeciwko Bogusławowi, a następnie także przeciwko 50 arianom (32 szlachcicom i 18 z czeladzi).

26 czerwca 1662 r. ksiądz Wieczorkowski z ośmioma ludźmi najechał folwark Białostoczek. W tym czasie arianie opuścili już dobra zabłudowskie i udali się do Prus. O samym zajeździe donosił jeden z pozwanych, Mikołaj Błoński, w liście do księcia Bogusława:

we dworze bydło wszystko pobrał, kłódki poodcinał, podłogi poodzierał, szukając tam z czeladzią jakichśs skarbów, z dobytemi szablami po dworze biegając, bijąc ludzi we dworze będących i tak koleją cały dzień mieszkanie nasze najeżżając rozbijał. Kury za nasze głowy męczennikami się stały, bo sam w kurniku zawarłszy się z niemi, rapirem ich ścinał ${ }^{38}$.

Starania księdza Wieczorkowskiego, by iure caduco przejąć dobra poariańskie (choć ci ostatni nie byli właścicielami, a jedynie dzierżawcami Białostoczka, Dojlid i Kurian), zakończyły się jednak niepowodzeniem. Po ugodzie księcia Bogusława z biskupem wileńskim Jerzym Białłozorem, że w posiadłościach radziwiłłowskich braci polskich nie będzie, kapłan został oddalony w 1665 r. z parafii zabłudowskiej, w której ulokowano „niewichrowatego” księdza Gulczewskiego ${ }^{39}$.

Początek drugiej połowy XVII w., ze względu na wyniszczające wojny ze Szwedami i Moskwą, był bardzo trudny dla podlaskich zborów, również z powodu wrogiego doń stosunku miejscowej ludności. Próbował temu zaradzić książę Bogusław:

Wszem wobec poddanym włości naszej orlenskiej. Doszło nas wiedzieć, że domy puste i opuszczone rozbieracie, i wniwecz całe obracacie po tym, gdyby się albo dziedzic wrócił, albo, osiadający trafił, domu mieć nie może. Przeto wydaję ten nasz list rozkazując, abyście pustoszenia domów opuszczonych koniecznie zaniechali pod winą zapłacenia domu ${ }^{40}$.

Zasłużonym dla podlaskich zborów i wiernych był też krewny Bogusława, Janusz, wojewoda wileński i hetman litewski. Realizując

38 Ibidem, s. 17.

39 Zob. ibidem, s. 22-24.

40 AGAD, AR, dz. XXIII, t. 105, p. 2 (Rozmaitości orlańskie), s. 19, List Bogusława Radziwiłła do starosty brańskiego, dan w Zabłudowie, 23 I 1664 r. O zniszczeniach zboru we wzmiankowanym czasie zob. M. Sierba, Kalwiński zbór orlański, BZH, 44, 2015, s. 53-58. 
„ostatnią wolę” swego ojca, Krzysztofa II Radziwiłła (testament spisany jeszcze we wrześniu 1619 r. w Dokudowie ${ }^{41}$ ), ufundował gimnazjum zabłudowskie:

Urodzonym PP. Urzędnikom i Rewisorom Majętności mojej Zabłudowskiej teraz i na tym będącym dla seminarium tutejsze, ordynowany ode mnie tysiąc złotych, abyście do rąk kaznodziei tutejszego co rok oddawali bez odwłok wszelakich, mieć chce i rozkazuję. Dan w Zabłudowie ${ }^{42}$.

Wedle Katalogu Discipulorum Scholae Zabludoviensis za 1685 r. uczyli się tam: primo classis: Samuel Sienicki, Krzysztof Sienicki, Jan Fisher, Zygmunt Mniszski, Stanisław Stankar, Aleksander Pękalski, Daniel Kamel, Władysław Prodecki; secundo classis: Michał Redzyński, Hieronim Zaharski, Aleksander Rusinowicz, Jan Andrzejewicz, Stefan Sienicki, Bogusław Olendzki; tertis classis: Bogusław Stankar, Krzysztof Balcerowicz, Andrzej Karmichel, Stefan Lis, Stanisław Lis, Andrzej Ramet, Dawid Bilfoer; quadros classis: Aleksander Wysocki, Paweł Walicki, Samuel Pawłowicz, Daniel Redzyński, Tomas Redzyński, Andrzej Plack (?), Daniel Karmichel ${ }^{43}$. Jak widać, w szkole kształcili się kolejni synowie Sienickich, Redzyńskich, Stankarów, Lisów czy Karmichelów.

Ostatnią kalwińską protektorką wiernych i zborów podlaskich była Ludwika Karolina Radziwiłłówna ${ }^{44}$, spadkobierczyni dóbr Janusza i Bogusława (wnuczka i córka wymienionych) i margrabina brandenburska (żona Ludwika Leopolda Hohenzollerna). Dwudziestoletnia księżna na Birżach i Dubinkach potwierdziła wcześniejsze akta wydane przez swoich poprzedników:

Czynię wiadomo i zeznawam tym listem moim dobrowolnym, wieczystym zapisem, iż [- - Z Zborom Ewangelickim, to jest Zabłudowskiemu, Orleńskiemu i Węgrowskiemu na Podlaszu będącym [- - z placami, mieszkaniami kaznodziejów, preceptorów, katechetów, z szkołą zabłudowską, a także z domami dla wdów, sierot, z szpitalnemi i ze wszystkimi, jako teraz zażywaja, przynależytościami, dla odprawiania nabożeństwa

${ }^{41}$ Zob. U. Augustyniak, Testamenty ewangelików reformowanych $w$ Wielkim Księstwie Litewskim, Warszawa 1992, s. 144-145.

${ }^{42}$ AGAD, AR, dz. VIII, sygn. 655, Akta uposażenia przez Radziwiłłów zboru ewangelickiego w Zabłudowie 1611-1774, s. 3, Rozkaz Janusza Radziwiłła, 25 IV $1654 \mathrm{r}$.

43 Ibidem, s. 12-13, Katalog Discipulorum Scholae Zabludoviensis Anno 1685.

${ }^{44}$ Zob. E. Bagińska, Spór o Ludwikę Karolinę Radziwittównę, „Białostocczyzna”, 4, 1997, s. 3-14. 
krześcijańskiego ewangelickiego w zborach ewangelickich, które Boga w Trójcy Jedynego, według Konfesyjej Helweckiej z Pisma św. wziętej, [- ] więc za te mianowane fundusze pod czas przeszłych z Szwedami i Moskwą w ojczyźnie naszej wojen poginęły, a zatym aby fundacyja tych zborów w opaczne jakie tłumaczenie w następujących potomnych czasach nie przychodziła, tym listem zapisem moim, odnoszącym do wiadomości teraźniejszego i napotym będącego $\mathrm{w}$ tchu, ludziom padaję. Te zbory [-] za prawem pospolitym względem wolnego nabożeństwa służącym przez książąt [- ] niech ku chwale Boga w Trójcy św. Jedynego są fundowane z nadaniem do nich sum różnych na obejście i sustentacyja ${ }^{45}$.

Cytowany zapis miał niezwykle istotne znaczenie, ponieważ po śmierci Ludwiki Karoliny w 1695 r. dobra te przejęli Radziwiłłowie nieświescy, już katolicy, cały czas jednak realizujący zobowiązania protektorów, zarówno w kwestiach organizacji wyznaniowej, jak i funduszy.

Spośród wymienionych trzech zborów koronnego „Podlasza” najlepiej udokumentowane są fundusze zabłudowskie, w tym $\mathrm{z}$ folwarku Rafałówka. Męskimi poddanymi Rafałówki na początku XVIII w. byli: „Hryc Kondratowicz syny Daniło, Eliasz, Nieście / Mikołaj Piotrowicz syny Andrzej, Jasko / Trochim Lapaczuk syn Jarosz, pasierbów 2 / Kaspar Wenthczyk? syny Bałtruk, Jan / Denis Żuk / Pawluk Pietraszyk, syny Maxim, Iwan Jasko Pitraszyk, syn Pawluk / Lasko Kuprysik / Oniszko Oleszko / Jasko Kuprianik, syn Michałko / Roman Chilecki, syn Pietruk / Dmitr Sidoryk, syn Samuyło / Chwier Prystupa" 46

$\mathrm{Z}$ podlaskich dóbr Radziwiłłów gwarantowano fundusze dla duchownych zborów zabłudowskiego i węgrowskiego ${ }^{47}$, zbór orlański

45 AGAD, AR, dz. VIII, sygn. 655, Akta uposażenia przez Radziwiłłów zboru ewangelickiego w Zabłudowie 1611-1774, s. 19-22, Kopia zapisu funduszowego na Zabłudowie, 30 VI 1687 r.

46 Ibidem, s. 53, Poddani w Rafałówce do Zboru Zabłudowskiego Fundowani - brak daty, jednakże dokument występuje w zestawieniu z funduszami wypłacanymi duchownym zabłudowskim w latach 1704-1707, można więc przyjąć podaną datację.

47 Por. ibidem, s. 60: „Księdzu Kopijewiczowi, Seniorowi Dystryktu Podlaskiego, Kaznodziei Zboru Zabłudowskiego wypłacono rocznego salarium a julio 1704 ad julium A 1705700 [- - ] Temuż Mci księdzu Kopijewiczowi ad rationem salarium rocznego wyłacono a julio A 1706 po dzień now<e>go lata zaczynającego się Roku 1707. 400 Księdzu Dyjakiewiczowi Kaznodziei Zboru Węgrowskiego salarium rocznego a julio A 1704 ad julium A 1705 wypłacono 800. Temuż Księdzu Dyjakiewiczowi salarium a julio A 1705 a julium A 1706 wypłacono z proventów Zabłud. zł czterysta a pożyczonych zł Dwieście summo podług kwitu 600”. 
Tabela 2. Pensje wypłacane duchownym różnych wyznań przez Radziwiłłów w 1732 r.

\begin{tabular}{|c|c|}
\hline Osoba lub instytucja, której wypłacano pensje & Kwota w zl \\
\hline \multicolumn{2}{|l|}{ duchowieństwo katolickie } \\
\hline ksiądz pleban słucki i kopylski & 1000 \\
\hline ksiądz pleban kojdanowski & 300 \\
\hline ksiądz lebiedziejowski & 200 \\
\hline kapituła wileńska & 1092 \\
\hline bonifratrzy wileńscy & 840 \\
\hline dominikanie wileńscy za dziesięcinę z włóki & 25 \\
\hline jezuici słuccy na lampę & 120 \\
\hline Razem & 3777 \\
\hline \multicolumn{2}{|l|}{ duchowieństwo ewangelickie (reformowane) } \\
\hline zbór zabłudowski i węgrowski - ponieważ przy orlańskim księdza nie mają & 1200 \\
\hline superintendent birżański z pomocnikami & 721 \\
\hline kaznodzieja birżański & 351 \\
\hline rektor szkoły zborowej & 264 \\
\hline zbór popielski & 338 \\
\hline zbór radziwilijski & 338 \\
\hline zbór świadowski & 338 \\
\hline zbory i pomocnicy kiejdańscy & 2800 \\
\hline zbór i kaznodzieja nowomiejski & 70 \\
\hline na wino do tych zborów & 200 \\
\hline Razem & 6727 \\
\hline \multicolumn{2}{|l|}{ duchowieństwo augsburskiej konfesji } \\
\hline kaznodzieja węgrowski & 400 \\
\hline kaznodzieja słucki & 400 \\
\hline kaznodzieja kiejdański & 400 \\
\hline kaznodzieja birżański & 400 \\
\hline Razem & 1600 \\
\hline \multicolumn{2}{|l|}{ duchowieństwo prawosławne } \\
\hline bractwo cerkwi Spaskiej w Słucku & 480 \\
\hline duchowieństwo cerkwi zamkowej Sobornej w Słucku & 20 \\
\hline pannom zakonnym przy cerkwi św. Eliasza & 20 \\
\hline Razem & 520 \\
\hline
\end{tabular}

Źródło: AGAD, AR, dz. VIII, sygn. 715, Akta uposażenia dawanego duchowieństwu różnych wyznań z dóbr radziwiłłowskich, później wittgensteinowskich i Hohenlohe 1670-1871, s. 5-6, Pensye wydawane Duchowieństwu kościołom Rozney Religii, które się pieniędzmi płacić zwykły od św. Jana Chrzciciela roku przeszłego 1732. 
od 1704 r. nie posiadał już stałego ministra. Warto w tym miejscu przyjrzeć się całkowitemu rocznemu funduszowi dla duchownych wszystkich wyznań chrześcijańskich, wypłacanemu przez Radziwiłłów w 1732 r. (zob. tab. 2). Mimo zmiany konfesji, ród pozostał wierny zobowiązaniom swoich przodków ${ }^{48}$ i najwięcej łożył na duchownych „wyznania helweckiego".

Sytuacja finansowa zborów objętych patronatem Radziwiłłów nie uległa zmianie w kolejnych dziesięcioleciach. Zachowane źródła wyraźnie wskazują na szczególne wsparcie dla ewangelickich zborów, zarówno na pensje dla duchownych, jak i inne potrzeby (zob. tab. 3). Zmiany nastąpiły wraz z rozbiorami Rzeczypospolitej, których konsekwencją były podziały organizacyjne dystryktów i ostateczna likwidacja dystryktu podlaskiego w latach $1796-1799^{49}$. Spośród zborów koronnego Podlasia nie istniały już reformowane w Orli i Węgrowie, pozostawał ten w Zabłudowie oraz luterański w Węgrowie, a także filia w Nurcu (zob. tab. 1). Jeśli idzie o cały były dystrykt podlaski, to rozbiory przetrwały też zbory w województwie brześciańskim: w Izabelinie $^{50}$, Jamnie i Niepokojczycach oraz po jednym w województwach trockim (Sidra) i lubelskim (Dokudów).

Tabela 3. Pensje wypłacane duchowieństwu i służbie zborów ewangelickich w dobrach Radziwiłłów w połowie XVIII w.

\begin{tabular}{|l|c|}
\hline \multicolumn{2}{|c|}{ Osoba lub instytucja, której wypłacano pensje } \\
\hline \multicolumn{2}{|c|}{ księża kaznodzieje ewangeliccy } \\
\hline zbór wileński & 4200 \\
\hline zbór kiejdański & 2500 \\
\hline księża przy zborze słuckim i rektor według fundacji & 3500 \\
\hline na wino i świece dla zboru słuckiego & 50 \\
\hline ksiądz kaznodzieja kopylski & 425 \\
\hline ksiądz kaznodzieja węgrowski & 800 \\
\hline ksiądz kaznodzieja sielecki & 300 \\
\hline
\end{tabular}

48 Zob.: W. Kriegseisen, Ewangelicy polscy i litewscy w epoce saskiej (1697-1763). Sytuacja prawna, organizacja, stosunki międzywyznaniowe, Warszawa 1996; K. Stojek-Sawicka, Pogranicza religijne - Radziwittowie wobec prawostawnych $i$ protestantów $w$ czasach saskich, BZH, 26, 2006, s. 29-51.

49 Zob.: M. Kosman, Litewska jednota ewangelicko-reformowana, s. 58; M. Liedke, Dystrykt podlaski, s. 69.

50 Zob. J. Maroszek, Inskrypcje ze zboru w Izabelinie, „Białostocczyzna”, 1, 1991, s. 19. 


\begin{tabular}{|l|c|}
\hline \multicolumn{1}{|c|}{ Osoba lub instytucja, której wypłacano pensje } & Kwota w zł \\
\hline na wino i świece dla zboru sieleckiego & 15 \\
\hline ksiądz zboru birżańskiego & 680 \\
\hline na wino i świece dla zboru birżańskiego & 200 \\
\hline rektor szkoły birżańskiej & 412 \\
\hline ksiądz kaznodzieja popielski & 320 \\
\hline na wino i na świece dla zboru popielskiego & 30 \\
\hline ksiądz kaznodzieja sołomiejski & 100 \\
\hline ksiądz kaznodzieja radziwiliski & 100 \\
\hline ksiądz kaznodzieja świadowski & 150 \\
\hline na świece i wino dla kaznodziei świadowskiego & 15 \\
\hline ksiądz kaznodzieja supraski? & 200 \\
\hline na świece dla bakałarzy & 40 \\
\hline ksiądz kaznodzieja zabłudowski i orlański & 300 \\
\hline katechista zboru zabłudowskiego & 150 \\
\hline na wino i świece dla zborów zabłudowskiego i orlańskiego & 30 \\
\hline ksiądz kaznodzieja kojdanowski, bakałarz, na wino i na świece do zboru & 200 \\
\hline ksiądz kaznodzieja bielicki & 200 \\
\hline & \\
\hline ksiądz kaznodzieja kościoła słuckiego & 300 \\
\hline ksiądz kaznodzieja kościoła birżańskiego & 150 \\
\hline ksiądz kaznodzieja kościoła kiejdańskiego & 200 \\
\hline ksiądz kaznodzieja kościoła węgrowskiego & 150 \\
\hline
\end{tabular}

Źródło: AGAD, AR, dz. VIII, sygn. 715, Akta uposażenia dawanego duchowieństwu różnych wyznań z dóbr radziwiłłowskich, później wittgensteinowskich i Hohenlohe 1670-1871, s. 7-8, Pensye dla Duchowieństwa i służby zborów ewangelickich, brak daty, zapewne po 1732 r., przed 1770 r. (rozwiązanie zboru w Orli).

\section{Zakończen i e}

Podlasie, leżące na styku Mazowsza, Rusi i Litwy, początkowo nie było atrakcyjną krainą dla wyznań reformacyjnych, m.in. ze względu na swoją różnorodność religijną i spełnianie części postulatów, występujących już w prawosławiu (język narodowy, „równość komunii” dla wszystkich wiernych, podporządkowanie władzy świeckiej). Ogromną rolę w szerzeniu protestantyzmu odegrał Mikołaj Radziwiłł „Czarny”, który nie bez przyczyny może być uznawany za „ojca” reformacji współczesnej Litwy i Białorusi. Jego religijna determinacja pociągnęła za sobą nie tylko potężny ród, ale też znaczną część innych litewskich 
i ruskich magnatów oraz średniozamożną szlachtę, w konsekwencji w krótkim czasie powstało w Wielkim Księstwie Litewskim około 200 zborów, kalwińskich i ariańskich.

Tereny województw podlaskiego i wyodrębnionego z niego brześciańskiego oraz obrzeży trockiego i lubelskiego objął dystrykt podlaski Jednoty Litewskiej. Liczba tworzących mu zborów ulegała zmianom, zwykle było ich około 10; również liczba dystryktów nie była stała - początkowo dwa, następnie sześć, a do końca istnienia Rzeczypospolitej dotrwało pięć.

Radziwiłłowie odegrali również istotną rolę w fundowaniu zborów, a następnie ich utrzymaniu. Po pierwszej fali reformacji na przełomie lat pięćdziesiątych i sześćdziesiątych XVI w. (i powstaniu wówczas rozległego dystryktu podlaskiego), następny okres organizowania przez nich zborów nastał w latach osiemdziesiątych (wyodrębnił się mniejszy dystrykt podlaski) oraz na początku XVII w., kiedy kontrreformacyjne działania spowodowały już upadek większości wspólnot protestanckich w Koronie. Także w bardzo trudnym dla innowierców czasie wojen Rzeczypospolitej z sąsiadami mogli oni liczyć na wsparcie potężnych protektorów w osobach Janusza czy Bogusława Radziwiłłów, demonizowanych później przez opiniotwórczego Sienkiewicza. Zachowane źródła archiwalne pozwalają wejrzeć nie tylko w organizację zborów na Podlasiu (dominowały sprawy funduszy, płaconych później przez już katolickich reprezentantów rodu Radziwiłłów), ale i trudy codziennego życia wiernych Kościoła ewangelicko-reformowanego, a także - rzadziej - arian czy luteranów.

\section{Bibliografia}

\section{Źródła}

AGAD, Archiwum Warszawskie Radziwiłłów: Rozmaitości orlańskie 1611-1704; Kurosz Stanisław, zarządca Orli 1620-1628; Akta uposażenia przez Radziwiłłów zboru ewangelickiego w Zabłudowie 1611-1774; Korespondencja Radziwiłłów z przedstawicielami synodów prowincjonalnych ewangelickich 1666-1807; Akta uposażenia dawanego duchowieństwu różnych wyznań z dóbr radziwiłłowskich, później wittgensteinowskich i Hohenlohe 1670-1871

Akta synodów prowincjonalnych Jednoty Litewskiej 1626-1637, wstęp i oprac. M. Liedke, P. Guzowski, Warszawa 2011

U. Augustyniak, Testamenty ewangelików reformowanych $w$ Wielkim Księstwie Litewskim, Warszawa 1992 


\section{Opracowania}

S. Augusiewicz, J. Jasiński, T. Oracki, Wybitni Polacy w Królewcu. XVI-XX wiek, wstęp i red. J. Jasiński, Olsztyn 2005

U. Augustyniak, Dwór i klientela Krzysztofa Radziwitta (1585-1640). Mechanizmy patronatu, Warszawa 2001

E. Bagińska, Dziatalność religijna Radziwittów birżańskich w dobrach podlaskich w XVII wieku, „Studia Podlaskie”, 12, 2002, s. 205-228

E. Bagińska, Spór o Ludwikę Karolinę Radziwittównę, „Białostocczyzna”, 4, 1997, s. 3-14

A. I. Bokun, Mikataj Radziwit Czorny: żyćcio i pamiać, w: Jevanhelskaja Carkva Bietarusi: historyja i suczasnasć. Zbornik materyjatau II Miznarodnaj navukova-praktycznaj kanfierencyi (Minsk, 5 snieżnia 2015 h.), red. P. I. Asienienka, J. A. Baczyszcza, A. I. Bokun, L. I. Michovicz, A. U. Unuczak, Minsk 2016

J. Hardziejeu, W kwestii stratygrafii spotecznej Grodna w pierwszej potowie XVI w., „Białoruskie Zeszyty Historyczne”, 16, 2001, s. 26-43

J. Jasnowski, Mikotaj Czarny Radziwitt (1515-1565). Kanclerz i marszatek ziemski Wielkiego Księstwa Litewskiego, wojewoda wileński, wyd. 2, Oświęcim 2014

T. Jasztołt, Fundacje kościelne na Podlasiu do końca XV wieku, w: Kościoty a państwo na pograniczu polsko-litewsko-biatoruskim. Źródta $i$ stan badań, red. M. Kietliński, K. Sychowicz, W. Śleszyński, Białystok 2005, s. 13-48

T. Kempa, Magnateria ruska wobec unii lubelskiej (1569), „Białoruskie Zeszyty Historyczne", 16, 2001, s. 5-25

M. Kosman, Historia Biatorusi, Wrocław 1979

M. Kosman, Litewska jednota ewangelicko-reformowana od potowy XVII w. do 1939 r., Opole 1986.

M. Kosman, Protestanci i kontrreformacja. $Z$ dziejów tolerancji $w$ Rzeczypospolitej $w$ XVI-XVIII wieku, Wrocław 1978

D. Krasnodębski, Badania Instytutu Archeologii i Etnologii PAN na terenie woj. biatostockiego (podlaskiego) w latach 1990-2005, w: H. Karwowska, A. Andrzejewski, Stan badañ archeologicznych na pograniczu polsko-biatoruskim od wczesnego średniowiecza po czasy nowożytne, Białystok 2006, s. 63-83

W. Kriegseisen, Ewangelicy polscy i litewscy w epoce saskiej (1697-1763). Sytuacja prawna, organizacja, stosunki międzywyznaniowe, Warszawa 1996

M. Liedke, Dystrykt podlaski w strukturze Kościoła ewangelicko-reformowanego $w$ Wielkim Księstwie Litewskim do końca XVIII wieku - źródta i stan badań, w: Kościoty a państwo na pograniczu polsko-litewsko-biatoruskim. Źródta i stan badań, red. M. Kietliński, K. Sychowicz, W. Śleszyński, Białystok 2005, s. 62-68

M. Liedke, Od prawostawia do katolicyzmu. Ruscy możni i szlachta Wielkiego Księstwa Litewskiego wobec wyznań reformacyjnych, Białystok 2004 
J. Łukaszewicz, Dzieje kościotów wyznania helweckiego w Litwie, t. 2, Poznań 1843

J. Maroszek, Dziedzictwo unii kościelnej w krajobrazie kulturowym Podlasia: 1596-1996, Białystok 1996

J. Maroszek, Inskrypcje ze zboru w Izabelinie, „Białostocczyzna”, 1, 1991, s. 19

D. Michaluk, $O$ możliwościach badań struktury etnicznej Podlasia w XVI wieku, „Białoruskie Zeszyty Historyczne”, 17, 2002, s. 57-72

J. Mironczuk, Reformacja na Mazowszu Pótnocnym (diecezja ptocka), „Studia Theologica Pentecostalia”, 4, 2016, s. 71-92

A. Mironowicz, Kościót prawostawny $i$ unicki $w$ Rzeczypospolitej $w$ latach 1596-1648, „Białoruskie Zeszyty Historyczne”, 5, 1996, s. 23-55

A. Mironowicz, $Z$ dziejów prawostawia na Biatostocczyźnie, „Białoruskie Zeszyty Historyczne”, 10, 1998, s. 12-23

A. Panasiuk, Reformacja na Podlasiu do potowy XVII wieku, Lublin 2004, mps pracy magisterskiej pod kier. prof. dr. hab. H. Gmiterka

M. Sierba, Kalwiński zbór orlański w XVII wieku, „Białoruskie Zeszyty Historyczne", 44, 2015, s. 45-61.

K. Stojek-Sawicka, Pogranicza religijne - Radziwittowie wobec prawostawnych i protestantów $w$ czasach saskich, „Białoruskie Zeszyty Historyczne”, 26, 2006, s. 29-51

K. Śleszyński, Struktura narodowościowa i wyznaniowa Zabtudowa w XVII wieku, „Białoruskie Zeszyty Historyczne”, 28, 2007, s. 23-34

J. Tazbir, Bracia polscy w Zabtudowie i Dojlidach, OiRwP, 52, 2008, s. 5-26

\section{Protestant Denominations in the District of Podlasie}

The article deals with the history of Protestant denominations, especially Calvinism and Arianism, in the area of the district of Podlasie, making part of the Lithuanian Unity of the Evangelical Reformed Church. The district existed in the years 1560-1796. The study sheds light on the history of the Reformation in Podlasie (and in the Grand Duchy of Lithuania in general), and contains a list of Protestant churches (altogether 23, with some "loose" groups of Arians in the neighbourhood of the town of Biafystok), active at that time in the district. Another element of the study is the depiction of the vicissitudes of the Protestant faithful under the protection of the Radziwilłs throughout the whole existence period of the district. This last part of the study is based on handwritten archival sources that, although known to researchers, have remained largely unquoted and unacknowledged; other parts of the study are based on the fairly rich literature on the subject, including articles in periodicals, collections of studies, and printed sources. 
Jan Mironczuk - ur. 1966 w Bielsku Podlaskim, mieszka pod Ostrołęką, kierownik Katedry Historii Kościoła w Wyższym Baptystycznym Seminarium Teologicznym w Warszawie, wykładowca filozofii i logiki w Wyższej Szkole Teologiczno-Społecznej w Warszawie. Zainteresowania badawcze: dzieje wyznań chrześcijańskich w Polsce w XIX-XX w. W ostatnim czasie zajmuje się reformacją na ziemiach polskich (Reformacja na Mazowszu Pótnocnym (diecezja ptocka), „Studia Theologica Pentecostalia”, 4, 2016).

Jan Mironczuk - (b. 1966 in Bielsk Podlaski), lives near Ostrołęka, head of the Chair of History of the Church at the Warsaw Baptist Theological Seminary, lecturer in philosophy and logic at the Theological-Social Higher School in Warsaw. His main scholarly interest covers the history of Christian denominations in Poland in the $19^{\text {th }}-20^{\text {th }}$ centuries. Recently, he got interested in the Reformation in Polish lands (e.g. he is the author of: "Reformacja na Mazowszu Północnym (diecezja płocka)", Studia Theologica Pentecostalia, 2016).

E-mail: janmir66@o2.pl 